\title{
The Greek Language Education in Albania: A Professional Development Framework for Greek Language Teachers
}

Spyros Bouras: Department of Primary Education, Faculty of Social Sciences and Humanities University of Western Macedonia.

\begin{abstract}
The main purpose of this study is the design, implementation and evaluation of a professional development program for Greek language teachers in minority education in Albania. The education of the Greek minority in Albania has been a separate part of the whole educational system of the country that has its own features and its own history (Barkas, 2011). The starting point of the present study will be to outline the existing educational situation and to explore the needs of a) the specific teachers and b) the views of the head teachers and c) the professors at the University of Argyrokastro in order to form an overall picture of their training needs, their views and their suggestions for continuing education. The ultimate goal is to present an integrated professional development context for Greek language teachers in the minority education in Albania and we hope that the suggested professional development program for minority education teachers will be an effective one to upgrade their work and, in the long run, to make a decisive contribution to the qualitative upgrading of the Greek language instruction.
\end{abstract}

Key words: Professional development program, Greek-Language education, Albania, Greek minority, Teachers.

\section{Introduction}

The program of minority schools in Albania, depending on the grade, includes the teaching of Greek as an autonomous language course or it is conducted exclusively in Greek. Compulsory Greek-language education is nine years with gradual reduction of hours in the last classes. At the same time, students in schools are also taught the Albanian language. According to Tsitselikis (2010) at the end of primary education, $60 \%$ of the program is taught in Greek, while the remaining $40 \%$ of the courses is in Albanian.

The overwhelming majority of Greek language teachers are graduates of either the Academic College of Argyrokastro, which operates as a vocational high school, or the Department of Greek Language, Literature and Culture at the University of Argyrokastro. At the same time, the lack of motivation coupled with the massive influx of many minority students in Greece during the past decade led to a very small number of young Greek language learners being interested in getting into minority education. However, in recent years, due to the economic crisis in Greece, members of the Greek minority returned to Albania and re-opened two schools in the prefecture of Agioi Saranta in villages that had been closed due to the "mass exit" to Greece (Rapti, 2014) the integration of these children being hampered by structural factors linked to the Albanian educational system (Vathi, Duci, \& Dhembo, 2016).

Moreover, the professional development of Greek-language teachers in Albania is extremely difficult and fragmented as it is not subject to an integrated scheme. Last year the University of Western Macedonia organized a two-day training meeting for teachers of the Greek language of the minority schools of Argyrokastro in Florina.

2020

DOI: $10.53935 / 2641-533 x . v 3 i 3.146$

Funding: This study received no specific

Received: 6 August 2020

Revised: 9 September 2020

Accepted: 29 September 2020

2020 19 October 2020

2020 by the authors; licensee Academic Publishing Group 
Regarding teachers' professional development issues, several changes have been observed and recorded in various educational systems on a global basis, aiming at improving education through in-service teacher training which plays a 'key role' both for teachers and studentsas well as for the school context in general.

The involvement of the teacher in continuing activities is crucial as it provides them with the necessary knowledge and skills. Besides, nowadays a teacher has to be "highly-professional" in order to develop collaborations and to ensure his or her continuous professional development (Griva \& Bouras, 2018). Bolam (2002) emphasizes the importance of professional development in the development of leadership skills by teachers so that they can train their students more effectively. Studies also highlighted the long-term implications of teachers' professional development, which are directly related to the development of greater confidence concerning their practice in the classroom (Buczynski \& Hansen, 2010; Harris \& Sass, 2011; Umrani, Ahmed, \& Memon, 2015; Zin \& Ibrahim, 2020).

Furthermore, it highlights the need for quality professional development programs that are well organized, long-term and coordinated with school teaching practice (e.g. (Desimone, 2009; Van den Bergh, Ros, \& Beijaard, 2014)). In this context, a variety of in-service training models has been proposed which vary according to diverse socio-political contexts and different objectives. The most innovative one is the hybrid model, the so called "blended learning model" which we propose in our study.

The "blended learning" model is defined as "learning that occurs in a structured educational context and is characterized by a combination of distance and face-to-face learning" (Boelens, Van Laer, De Wever, \& Elen, 2015). This model is widely used in higher education or adult education and its successful implementation is directly related to the teaching, cognitive and social presence of trainees, emotional involvement as well as their motives (Alzgool, 2019; Khalid, Islam, \& Ahmed, 2019; López-Pérez, Pérez-López, \& Rodríguez-Ariza, 2011; Rovai \& Jordan, 2004).

\subsection{The Purpose of the Study}

The main purpose of this study is the design, implementation and evaluation of an integrated professional development program for Greek language teachers in the schools of minority Greek education in Albania based on modern continuing models. More specifically, the starting point of the present study will be to outline the existing educational situation and to explore the professional development needs of the specific teachers, the views of the head teachers and the professors at the University of Argyrokastro in order to form an overall picture of their training needs, their views and their suggestions for continuing education. These are the three key groups which define the minority educational situation in Albania.

The design and implementation of the professional development program will be based on the hybrid model combining face to face teachings and ICT with the use of the Learnworlds platform (http://www.learnworlds.com) which offers the opportunity to create a multimedia and multimodal context in which teachers will be able to interact, communicate and collaborate through multiple types of activities. From this point of view, we hope that this professional development program will be an important proposal for upgrading the work of minority teachers in Albania and will make a decisive contribution to the qualitative upgrading of the teaching of the Greek language.

Finally, we are optimistic that this professional development program will lead to the acquisition of appropriate skills and will change the professional practice as well as the teaching behavior of the specific group of teachers, but also have prospects for future use for other continuing actions, too.

\subsection{The Objectives of the Survey}

The key objectives can be summarized as follows:

i. To map the educational needs of minority Greek-language education in Albania as presented by the teachers themselves

International Journal of Educational Studies

Vol. 3, No.3, pp. 106-112

2020

DOI: $10.53935 / 2641-533 x . v 3 i 3.146$

Funding: This study received no specific

financial support.

Article History:

Received: 6 August 2020

Revised: 9 September 2020

Accepted: 29 September 2020

Published: 19 October 2020

(C) 2020 by the authors; licensee Academic

Publishing Group

ii. To record their expectations of the professional development programs and the teachers' views on the organization, content and evaluation of these programs

iii. To record their training needs in relation to theoretical issues of linguistic development and regarding modern approaches and methods of teaching the Greek language

iv. To list the views and suggestions of directors and teaching staff at the University of Argyrokastro regarding the organization, content and evaluation of the professional development programs

v. To design a professional development program that takes into account existing needs and builds on the 
principles of adult training and design of modern training models

vi. To apply the professional development program so as to develop educational knowledge, classroom management skills with Greek as heritage language and evaluate its effectiveness

1.3. Description of the Research Questions Faced by the Proposed Research and the Long-Term Perspective Depending on the research objectives, the following research questions arise:

- What are the most important educational needs of teachers?

- What reflections and what proposals for the teaching of the Greek language will the teachers have?

- What are the teachers' preferences and what are their proposals for the design, implementation and evaluation of professional development programs on teaching the Greek language?

- What is the contribution of the hybrid professional development program to develop teachers' knowledge, skills, behaviours, values and attitudes about the Greek language?

- How is the effectiveness of the training program evaluated by teachers?

\section{Methodology / Implementation Plan}

In the context of this research, a multi-methodological approach, defined as triangulation approaches the complexity of human behavior by examining it from different perspectives using quantitative and qualitative data. The survey sample in the first stage of the program will consist of three groups:

a) Teachers of minority Greek education in the area of Argyrokastro, Delvino, Agioi Saranta

b) Head teachers of the respective schools

c) Professors at the University of Argyrokastro.

These are the three key groups which define the minority educational situation in Albania.

The following table sets out the methodology to be followed and the five successive stages of the research, design, implementation and evaluation of the program Figure 1.

Stages of research Process

\section{Stage 1: Overview}

a)the theoretical context of Greek- language education in Albania,

b) the theoretical context of adult education,

c) modern needs for language education,

Stage 2: Investigation

d) the educational needs of minority Greek education in Albania

e) the specific conditions for the implementation of language training to

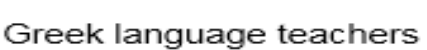

3rd Stage: Planning the continuing program
Methods of implementation

\section{Bibliographic review}

- thetheoreticalcontextofadulteducation, aswellas principles and models for the design of training programs

- the theoretical context of minority Greekeducation in Albania, and the current educational policies for minority Greek education in Albania

Use of quantitative and qualitative tools to map the educational needs of minority Greek education in Albania by completing a) questionnaires from Greek language teachers and b) with the head teachers of these schools and c) semi-structured interviews with the professors at the University of Argyrokastro.

- Setting goals and organizing content, educational methodology, context and evaluation of the program.

- A blended learning model combining lifelong learning with distance learning will follow, utilizing the Learnwolds platform (http://wmw.learnworlds.com) with the former taking place in face-to-face meetings and the later in the private, personal space of each teacher.

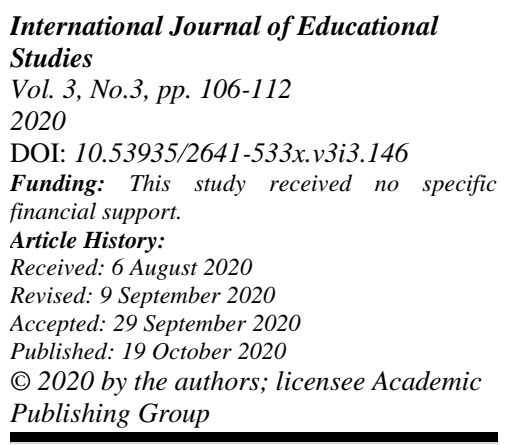

| 108 
Stage 4: Implementation of the continuing program

- Implementation of training with the participation of Greek minority education teachers from Albania - in an active context which will give teachers opportunities for active participation, interaction and collaboration in decision-making and problem-solving.

- The program will also contain pedagogical and educational design in authentic learning environments through micro-teaching.

- The ambition of the program is to educate teachers on innovative tools for the management of educational material as well as on new modern methods in the teaching of the Greek Language.

- Initial - Formative and Final Evaluation of the program with:

- scale of expectations,

- diaries,

- self-assessment sheets of the trainees,

- focus groups discussions,

- questionnaires program

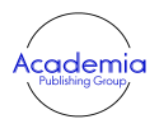

International Journal of Educational Studies

Vol. 3, No.3, pp. 106-112

2020

DOI: $10.53935 / 2641-533 x . v 3 i 3.146$

Funding: This study received no specific

financial support.

Article History:

Received: 6 August 2020

Revised: 9 September 2020

Accepted: 29 September 2020

Published: 19 October 2020

(C) 2020 by the authors; licensee Academic Publishing Group
Stage 5: Evaluation of the continuing

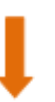

Formulation of an integrated professional development proposal for Greek minority education teachers in Albania

Figure-1. Methodological Planning and Stages of implementation of the research.

\subsection{Stages of the Research}

The proposed research will be implemented through five main stages:

1 \& 2 Stages: Recording the current situation of minority Greek education in Albania

In the first two stages we will explore the existing situation in the educational system of minority Greek education in Albania. In order to formulate a coherent theoretical framework for the design and implementation of the professional development programs, the relevant bibliographic (secondary) review will be used.

A SWOT ANALYSIS will be conducted at a four-level:

\begin{tabular}{|l|l|}
\hline Features - Pros / Strengths & Weaknesses \\
\hline Opportunities & Threats \\
\hline
\end{tabular}


In these stages we will also include a series of empirical surveys to highlight the critical factors associated with effective design and effective implementation of education policies and programs at different levels of planning. More specifically, a mapping of the educational needs of minority Greek education in Albania will be carried out by completing questionnaires from Greek language teachers and with head teachers of the respective schools as well as by conducting interviews with the teaching staff of the University of Argyrokastro. For this reason it is necessary to carry out a preliminary control of the tools to be used in the present study in order to acquire personal perception about the subject to be examined and to identify the research tools that will be used.

At the beginning we will visit some minority schools in the area of Argyrokastro and we will discuss informally with teachers in order to collect as much information as possible about their needs and concerns on the issue of their training. At the same time questionnaires will be distributed in their first form and pilot interviews will be taken. The answers of the pilot questionnaires and interviews will be used as feedback to improve some questions.

At the same time, pilot interviews will be taken with the professors at the University of Argyrokastro with a view of identifying possible omissions and rewriting in their final form and questionnaires will be distributed in a random sample of head teachers of Greek minority education in Albania. Then, the questionnaires will be distributed to the teachers as well as head teachers in their final form and interviews with the professors of the University of Argyrokastro will be held. The collection will follow, and then

a) The quantitative analysis of the questionnaire data;

b) The qualitative analysis of interview data.

\section{Stage 3: Designing a continuing program for Greek language teachers for the schools of Argyrokastro,} Delvino and Agioi Saranda

In the third stage of the research, based on the results of the bibliographic review, the mapping of the educational needs of the minority as well as the bibliographic review of the principles and the modern training models, a continuing program for language teachers of the Greek minority in Albania will be held. The design of the professional development program will include the definition of the purpose, the specific training objectives, the configuration of the educational content, the training methods and techniques, as well as a series of organizational issues (selecting trainees, choosing a coordinator and supporting staff for the implementation, selection of trainers, timetable, training materials, teaching aids, etc.). In particular, the innovative "blended learning model", which is the most appropriate for the training of teachers in even remote areas, will be applied and which is compatible with at least five of the principles of adult education as the trainees (a) understand the reason that they are trained (b) learn at their own pace; (c) learn through their experience; (d) adjust their apprenticeship time and (e) are encouraged and supported throughout the program. By following the hybrid model, the training program will combine lifelong learning with distance learning, the former to take place in face- to-face meetings, and the latter in the private, personal space of each teacher.

\section{Stage 4: Implementation of the continuing program}

In the fourth stage of the research, implementation of the training will take place. The training program will be implemented with the participation of teachers from different areas of Greek minority education in Albania such as Argyrokastro, Delvino, Agioi Saranta. The educational objectives of the program will include the development of knowledge, abilities, behaviours, values and attitudes related to the teaching of the Greek language, combined with the use of new technologies, in accordance with the training needs identified. The training actions will be implemented in an active context which will provide opportunities for teachers to actively participate, interact and collaborate in decision-making and problem-solving. Therefore, special emphasis will be placed on interventions that will facilitate verbal communication, interaction and cooperation among teachers. For this reason, the promotion of collaboration and the learning of new cognitive phenomena will be held through group activities where teachers will interact, use the language creatively and actively participate in activities that they will carry out by acting together. The program will also contain pedagogical and educational design of teaching in authentic learning contexts through micro-teaching. The main focus will be on training teachers capable of creating their own program for the teaching of the Greek language. The ambition of the program is to educate teachers on innovative tools for the management of educational material and their classroom as well as on new modern methods in the teaching of the Greek Language.

Vol. 3, No.3, pp. 106-112

2020

DOI: $10.53935 / 2641-533 x . v 3 i 3.146$

Funding: This study received no specific

financial support.

Received: 6 August 2020

Revised: 9 September 2020

Accepted: 29 September 2020

Published: 19 October 2020

Publishing Group

| 110 
Stage 5: Evaluation of the continuing program

The completion of the first three stages of the survey will allow, in the fifth and final stage, to evaluate, support and develop a proposal for the effective integration of professional development in the designing of educational and human resources development policies for Greek minority education in Albania, based on the modern political, social, economic and technological reality. The evaluation of the professional development program is important in order to ensure a high level of its efficiency in its design and effectiveness. For this reason, the methodological practice of combining the different methods with the tools to be used will be the scale of expectations, self-assessment sheets of the trainees, the researcher's diary, focus groups discussions with the trainees and questionnaires for the implementation of the new knowledge and exploitation of the written essay that will allow not only the immediate and active involvement of the participants but also the development of a reflective process.

\subsection{Concluding Remarks}

The modern teacher plays a pivotal role as he / she has to constantly be renewed in order to have positive results, with professional development being crucial to improving the learning process (Meissel, Parr, \& Timperley, 2016). Thus, teacher participation in training activities is decisive as it provides them with the necessary knowledge and skills. Teacher professional development is a key component of the educational process as it is directly linked to school upgrading, enhancing the quality of the educational work and improving pupil performance (Witte \& Jansen, 2016). Besides, the upgrading of Greek-language schools in the formal and the non-formal educational system plays a decisive role in the preservation of national identity of this minority community in Albania (Sotiroudas, Tsakiridou, \& Griva, 2017). Moreover, the professional development of Greek-language teachers in Albania is extremely difficult and fragmented as it is not subject to an integrated scheme.

Through the present study we hope to present a comprehensive proposal that will include the design, implementation and evaluation of training programs for Greek language teachers in the minority educational system of Albania. These are organized interventions based on the blended learning model, which exploits the advantages of traditional lifelong learning with modern and asynchronous transmission technologies, creating the right conditions for a thorough professional development proposal.

We propose a hybrid professional development model that takes into account the educational needs of the minority education involved parties in Albania and a part of which will take place through the Learnworlds platform, which is appropriate for achieving the research goals we have set because of the variety of tools and multimedia. It provides the easy management and processing but mainly because it offers the possibility of creating an interactive learning context, which gives the primary role to the trainees. With the appropriate teaching design and using all the tools and multimedia that it offers, it constitutes an innovative and creative learning tool with the proposed professional development model having prospects for exploitation in other training actions in the future as we can address this program to a specific group of teachers, but it will also be an integrated professional development context, contributing decisively to the qualitative upgrading of the instruction of the Greek language.

\section{References}

Alzgool, M. (2019). Nexus between green HRM and green management towards fostering green values. Management Science Letters, 9(12), 2073-2082

Barkas, P. (2011). Bilingualism and national identity in the Northern Epirus. Paper presented at the International Conference of the Department of German Language and Literature on "Languages and Cultures in (Dis) Action, 25-28 May 2011. Thessaloniki.

Boelens, R., Van Laer, S., De Wever, B., \& Elen, J. (2015). Blended learning in adult education: Towards a definition of blended learning.

Bolam, R. (2002). Professional development and professionalism. In Bush T. \& Bell, L. (Eds), The Principles and Practice of Educational Management. London: Paul Chapman Publishing.

Studies
Vol. 3, No.3, pp. 106-112

2020

DOI: $10.53935 / 2641-533 x . v 3 i 3.146$

Funding: This study received no specific

financial support.

Article History:

Received: 6 August 2020

Revised: 9 September 2020

Accepted: 29 September 2020

Published: 19 October 2020

(C) 2020 by the authors; licensee Academic

Publishing Group

Buczynski, S., \& Hansen, C. B. (2010). Impact of professional development on teacher practice: Uncovering connections. Teaching and Teacher Education, 26(3), 599-607.

Desimone, L. M. (2009). Improving impact studies of teachers' professional development: Toward better conceptualizations and measures. Educational Researcher, 38(3), 181-199.

Griva, E., \& Bouras, S. (2018). Upporting in-service training of language teachers in the modern European education environment. Paper presented at the Proceedings of 2nd International Research Conference "Internationalization of Higher Education of Ukraine in Global Multicultural Space. 
Harris, D. N., \& Sass, T. R. (2011). Teacher training, teacher quality and student achievement. Journal of Public Economics, 95(7-8), 798-812.

Khalid, N., Islam, D. M. Z., \& Ahmed, M. R. M. (2019). Sentrepreneurial training and organizational performance: Implications for future. Humanities \& Social Sciences Reviews, 7(2), 590-593.

López-Pérez, M. V., Pérez-López, M. C., \& Rodríguez-Ariza, L. (2011). Blended learning in higher education: Students' perceptions and their relation to outcomes. Computers \& Education, 56(3), 818-826.

Meissel, K., Parr, J. M., \& Timperley, H. S. (2016). Can professional development of teachers reduce disparity in student achievement? Teaching and Teacher Education, 58, 163-173.

Rapti, A. (2014). Educational policy on Greek-language education in Albania: Exploring teachers' and students' needs for the teaching / learning of the Greek language. MSc Thesis. Thessaloniki: University of Macedonia.

Rovai, A. P., \& Jordan, H. M. (2004). Blended learning and sense of community: A comparative analysis with traditional and fully online graduate courses. International Review of Research in Open and Distributed Learning, 5(2), 1-13.

Sotiroudas, B., Tsakiridou, E., \& Griva, E. (2017). The diversity of Greek-language education in Albania. Paper presented at the 1st International Conference, The New Greek Language in the Black Sea Area and the Balkans. Komotini, 30 September - 2 October 2016.

Tsitselikis, K. (2010). Education of the Greek minority in Albania. In: The Greek minority of Albania. Education and demographic mobility in Greece and Albania [Research of the Minority Research Center].

Umrani, W., Ahmed, U., \& Memon, P. (2015). Examining the absorptive capacity construct: A validation study in the Pakistani banking context. Management Science Letters, 5(12), 1053-1058.

Van den Bergh, L., Ros, A., \& Beijaard, D. (2014). Improving teacher feedback during active learning: Effects of a professional development program. American Educational Research Journal, 51(4), 772-809.

Vathi, Z., Duci, V., \& Dhembo, E. (2016). Homeland (dis) integrations: Educational experience, children and return migration to Albania. International Migration, 54(3), 159-172.

Witte, T. C., \& Jansen, E. (2016). Students' voice on literature teacher excellence. Towards a teacher-organized model of continuing professional development. Teaching and Teacher Education, 56, 162-172.

Zin, M. L. M., \& Ibrahim, H. (2020). The influence of entrepreneurial supports on business performance among rural entrepreneurs. Annals of Contemporary Developments in Management \& HR (ACDMHR), 2632-7686.

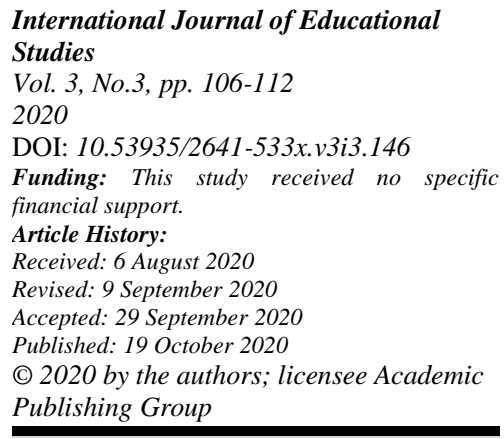

112 